\title{
盲幼児の食生活について \\ Daily Diet of Pre-School Blind Children
}

東京都心身障害者福祉センター視覚障害科

(Tokyo Metropolitan Rehabilitation Center for the Physically and Mentally Handicapped)

五十嵐信 敬 (Nobutaka Igarashi)

purpose:

(1) Clarification of the situation of unbalanced diet and poor eating of blind children.

(2) Clarification of the daily diet of blind children.

(3) The observation of the relationship between dietary habits and the reason for unbalanced diet and poor eating.

(4) The observation of the relationship between unbalanced diet and poor eating and retarded physical and mental growth.

a description of the investigated group:

A group of 39 blind children from the ages of 2 to 6 years. method:

A group of 17 partially blind children completed a questionnaire to serve as the control group. conclusion:

(1) A great number of blind children suffer from unbalanced diet and poor eating, but the majority of blind children do not suffer from these factors. However, the mentally retarded are more apt to suffer from unbalanced diet and poor eating.

(2) A great many blind children are let to do as they likes by their mothers, and especially, in the case of the mentally retarded children this situation is extremely likely to develop. Therefore parental behavior is one cause of unbalanced diet and poor eating for blind children.

\section{I は じめに}

従来, 盲児には偏食や少食の者が多い事が, 盲教育関係者によって指摘されてきている。しかし, 偏食や少 食は個体の置かれている条件によって左右される事は周知の事実である。したがって, 寄宿舎生活者の多い盲 児と家庭生活をしている普通児とを比較して, 盲児に偏食や少食の者が多いからと言って, それを盲児の特性 として把光る事は危険である。そこには視力欠損がその要因として働いている根抛は希薄なわけである。そこ でこのような研究においては，なるべく同一条件の二集団を比較するのが望ましい。

ところで，偏食傾向の形成は幼児期の育児態度によるところが多い。その点からは，幼児期の盲児について， 食生活の実態を明らかにする事は, 我々に新たな知見を与光る事になろう。しかし, 一定数の盲幼児を獲得す ることは極めて困難な事である1)。幸いにして, 筆者は多くの盲幼児に接する機会を得たので，次の二点を基 本線として研究を進めた。この報告はその一部である。

(1)盲幼児を対象とする。

(2)対象児となるべく同一環境下のコントロールグループと比較する。 


\section{II 研 究 の 目的}

本研究は盲幼児の食生活の実態を調査によって解明する事を目的としている。具体的には次の 4 点を研究目 標として，資料を分析・考察する。

(1盲幼児の偏食 ${ }^{2)}$ おび少食 ${ }^{3)}$ の実態を明らかにする。

(2)盲幼児の食習慣の実態を明らかにする。

(3)盲幼児の偏食怙よび少食の原因の一面を食習慣との関連で考察する。

(4)偏食盲児・少食盲児の発達状況を明らかにし, 偏食括よび少食と発達遅滞との相互関係について考察する。

\section{III 研究の方法}

1. 調査方法

質問紙を作製し，郵送法によって調査する。

2. 調査内容

調査は次の 3 つの下位調査からなる質問紙によって実施される。

・調査 1 ：偏食に関する調査 ${ }^{4)}$

・調查 2 : 食酌慣に関する調查 ${ }^{5)}$

- 調査 $3:$ 摂取食品に関する調査 (2 日分)

\section{3. 調查期間}

調査期間は昭和 45 年 3 月〜 4 月である。

4. 調查対象

$2 \sim 6$ 才の視力 0.3 未満の視覚障害児82名の親に質問紙を郵送し，63通を回収。（回収率 : $76.8 \%$ ) 回収された質問紙のうち，集計可能なるの56通。（有効率：68.3\%）

5. 研究対象

全盲児 ${ }^{6)}(2 \sim 6 才)$

準盲・弱視児 ${ }^{7)}(2 \sim 6$ 才 $)$

$$
\text { 計 } 56 \text { 名 }
$$

本研究では準盲・弱視児がコントロールグループとして，全盲児との比較対象の役割をもっている。

6. 分析方法

本研究に拈ける分析方法は統計的手法（主に平均値の比較）を採用しているが，補足的方法として事例研究 法を加えている。

\section{IV 研究の結果および考察}

1. 偏食に関して

40 種の食品に対する嗜好傾向を準盲・弱視児と比較すると第 1 表のと括りである。この表より判断し, 全盲 児にみられる傾向として, 食べない食品が多いといら結果が指摘される。すなわち, 平均的に言えば盲幼児に は偏食の傾向が強いという事である。（結論 1 ）

次に, 各食品に対する嘫好傾向についてみると,一般的には全盲児と準盲・弱視児の間には顕著な違いは存在 
第 1 表 各種食品に対する嘴好

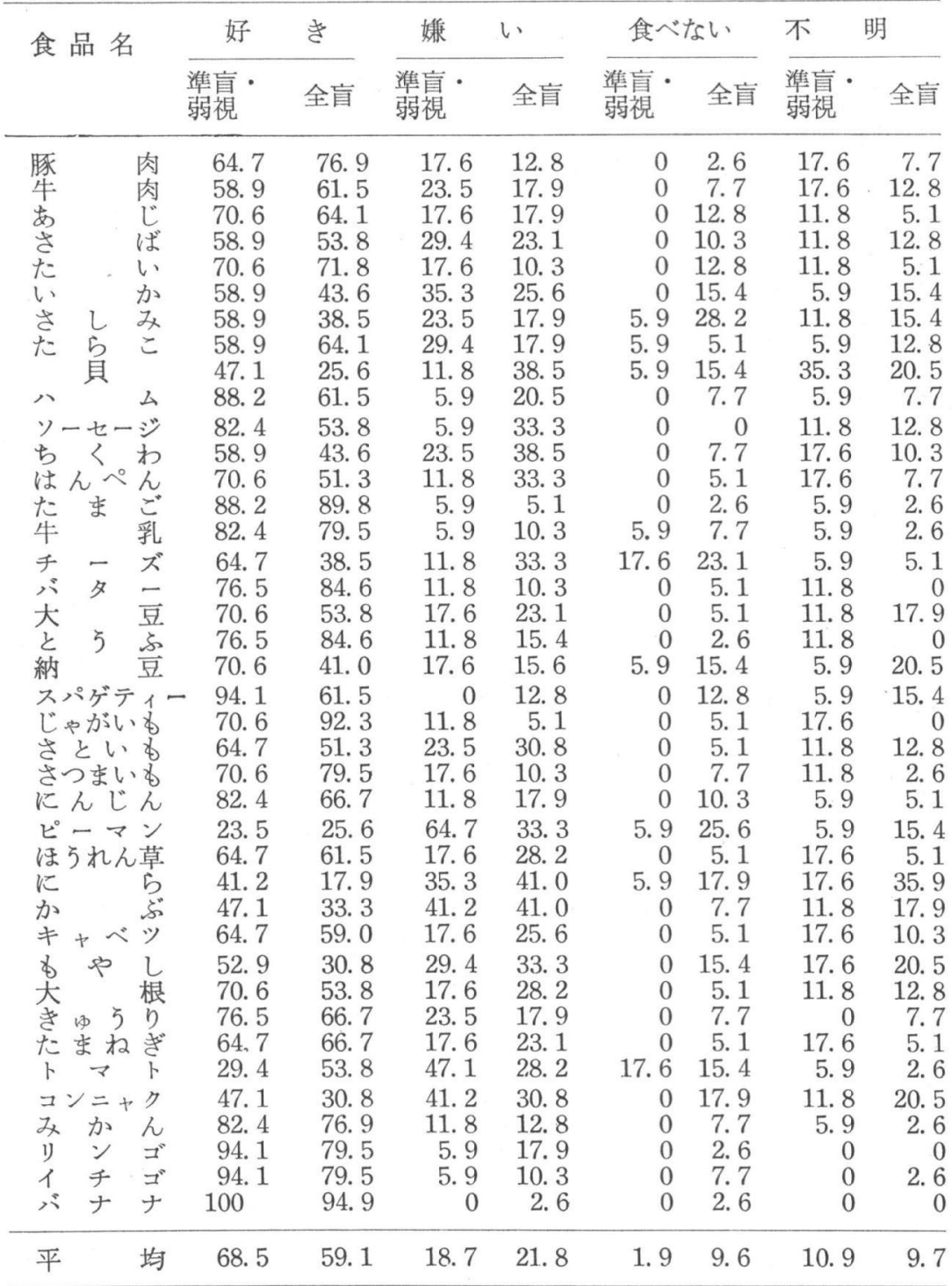

しないことがわかる。全 盲児が好きな食品は準盲 ・弱視児も好きであり, 逆 に全盲児が嫌いだったり 食べなかったりする食品 に対しては準盲・弱視児 もとうである事を第 1 表 は示している。攵の中に あって「いか」さしみ」 「貝」「納豆」「ピーマン」 「にら」「すやし」「コン ニャク」の 8 食品は全盲 児の方がかなり偏食傾向 が強いけれども，これら の食品は普通児も嫌いな 者の多い食品であって， 必ずしも盲幼児の特徴と は言觉ない。すなわち， 偏食の原因を視力欠損に 求める事は, 盲幼児の場 合は意味のない事だと言 える。(結論 2 ) それは 盲幼児の場合は, 食事作 法が完全自立している者 が少なく, 多少とも親の 介助を受けているので

「食べにくい」という要因が嗜好に影響しないためでめると考えられる。

第 2 表 ひとり当りの偏食食品 数の分布

\begin{tabular}{ccc}
\hline 偏食食品数 & 漼盲・ & 全盲 \\
\hline $0 \sim 2$ & 15名 & 22 名 \\
$3 \sim 5$ & 2 & 6 \\
$6 \sim 8$ & & 4 \\
$9 \sim 11$ & & 4 \\
$12 \sim 14$ & & 1 \\
15 以上 & & 2 \\
\hline
\end{tabular}

ところで，結論 1 に怙いて，盲幼児には偏食傾向が強い事が明らかにさ れた。しかし，これだけでは，盲幼児は全員が多かれ少なかれ偏食の傾向 があるのか，それとも極度に偏食の者が多いのかはわからない。そこで， その点を明白にするために, ひとり当りの偏食食品数を算出し, その分布 を表示したのが第 2 表である。

この結果からひとりで 6 食品以上に偏食を示している盲幼児が 11 名 （28. $2 \% ）$ もいる事がわかる。準盲・弱視児にはその上うな者が 1 名もい ない事と比較すると大きな違いである。すなわち，偏食は盲幼児全体の傾

向ではなく, 極度に偏食傾向を示す者が多いけれども, 何ら偏食のない者が大半を占めているのである。（結 論 3 ) 
第 3 表 栄養成分の不足の分布

\begin{tabular}{|c|c|c|c|c|c|c|}
\hline & \multicolumn{3}{|c|}{ 準盲・弱視 } & \multicolumn{3}{|c|}{ 全 盲 } \\
\hline & $\begin{array}{l}\text { 不足 } \\
\text { なし }\end{array}$ & $\begin{array}{l}\text { 不足 } \\
\end{array}$ & 不足 & $\begin{array}{l}\text { 不足 } \\
\text { なし }\end{array}$ & $\begin{array}{l}\text { や户 } \\
\text { 不足 }\end{array}$ & 不足 \\
\hline カロリー & $\begin{array}{r}\% \\
46.1\end{array}$ & 23.1 & 30.8 & $\begin{array}{r}\% \\
30.0\end{array}$ & 23.3 & 46.7 \\
\hline 蛋 白 質 & 61.5 & 7. 7 & 30.8 & 46.7 & 13.3 & 40. \\
\hline & 92.3 & 0 & 7.7 & 93.3 & 3.3 & 3. \\
\hline ビタミンA & 53.8 & 15. 4 & 30.8 & 53.3 & 20.0 & 26.7 \\
\hline ビタミン $\mathrm{B}_{1}$ & 61.5 & 23. 1 & 15. 4 & 60.0 & 26.7 & 13. \\
\hline ビタミン $\mathrm{B}_{2}$ & 69.2 & 23.1 & 7.7 & 80.0 & 6.7 & 13. 3 \\
\hline ビタミンC & 61.5 & 23.1 & 15. 4 & 63.3 & 26.7 & 10. \\
\hline
\end{tabular}

第 4 表 盲幼児の食習慣

1）一家そろって夕食が食べられますか。

\begin{tabular}{lrr}
\hline & $\begin{array}{c}\text { 集盲 } \\
\text { 弱視 }\end{array}$ & 全盲 \\
\hline 毎晚以上 & 35.3 & 23.1 \\
20日日旦上 & 29.4 & 7.7 \\
15日旦 & 5.9 & 20.5 \\
14日䚿 & 17.6 & 35.9 \\
無記入 & 11.8 & 12.8 \\
\hline
\end{tabular}

2）食事中は話をしますか。

\begin{tabular}{|c|c|c|}
\hline & 漼㒻・ & 全盲 \\
\hline $\begin{array}{l}\text { 息由に話す } \\
\text { 制限してい } \\
\text { 禁している } \\
\text { 無え記入 }\end{array}$ & $\begin{array}{r}76.5 \\
17.6 \\
0 \\
5.9\end{array}$ & $\begin{array}{r}89.8 \\
2.6 \\
7.7\end{array}$ \\
\hline
\end{tabular}

3 ）食事中どんなことに注意していますか。

\begin{tabular}{|c|c|}
\hline & 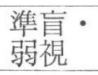 \\
\hline 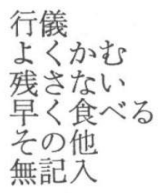 & $\begin{array}{r}33.3 \\
15.2 \\
33.3 \\
6.1 \\
12.1 \\
0\end{array}$ \\
\hline
\end{tabular}

4）偏食に対してどのようにしていますか。

\begin{tabular}{|c|c|c|}
\hline & 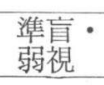 & 全盲 \\
\hline 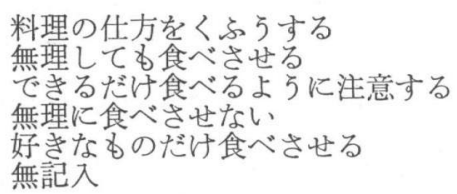 & $\begin{array}{r}40.0 \\
0 \\
45.0 \\
15.0 \\
0 \\
0\end{array}$ & $\begin{array}{r}28.9 \\
0 \\
33.3 \\
31.1 \\
6.7 \\
0\end{array}$ \\
\hline
\end{tabular}

2. 少食に関して

調査 3 の 2 日分の摂取食品について分析し ${ }^{8)}$, 各成分ごとに年令別栄養所要量9) より $15 \%$ 以上不 足を「やや不足」，30\%以上不足を「不足」とし て整理した。その資料のうちカロリー, 蛋白質, 脂肪, ビタミン $\mathrm{A} \cdot \mathrm{B}_{1} \cdot \mathrm{B}_{2} \cdot \mathrm{C}$ に関して, 各成分ご とに「不足なし」「やや不足」「不足」の分布を表 示したのが，第 3 表でめる。

この表より, 全盲児も準盲・弱視児も脂肪には ほとんど不足はみられず，ビタミン類には不足に 関しては差異が存在しない事がわかる。ところが カロリー, 蛋白質については全盲児の方に不足者 がかなり多く見られる。すなわち，盲幼児には少 食児が多い事がわかる。（結論4）しかし, 少食 に関しては, 準盲・弱視児にもみられる傾向であ り, 今後, 普通児との比較も必要である。

\section{3. 食習慣に関して}

調査 2 の食習慣に関する調査のうち, 偏食や少 食に影響すると思われる項目 4 ついいて表示す ると第 4 表の上 5 になる。

この結果から盲幼児の食習慣について，次のよ らな準盲・弱視児との差異が存在する事がわかる。 (1)食事を家族と一緒にする機会の少ない者が多い。 (2)食事中ほとんどの盲幼児が何の制限も受けず,

自由におしゃべりをしている。

(3)食事中「残さない上うに」との指示を与兄られ る者が準盲・弱視児より少ない。

(4)偏食に対して, 料理にくふらをしたり食べるよ らに注意されたりする者が準盲・弱視児より少 なく,逆に, 無理には食べさせられない者が多い。 以上の点をまとめると, 盲幼児は, 放任された 環境の中で, 食習慣を形成させて扣り, 偏食や少 食に対して子積極的な指導を受けていない者が多

い事になる。（結論 5 ）一般的に, 普通児の場合ならば, 偏食や少食については母親から必要以上の矯正指導 を受けるのであるが，盲児の場合は，母親の心が障害の方へ向いているため, 偏食や少食等は見落されてしま らのであろう。この食事に対する母親の態度が盲幼児の偏食や少食の一原因となっているのである。（結論 6 ） さらに, この母親の態度は，単に食生活にとどまらず，育児態度全般を支配しているわけで，盲幼児の健全な 
成長に何らかの影響を与学るであろう事は容易に想像がつく。

4. 偏食招よび少食と発達との関連に関して

第 5 表 偏 食 巟 の 特 徴

\begin{tabular}{|c|c|c|c|c|c|c|}
\hline 氏名 & 年令 & 性 & 身体発育 & 運動能力 & 言語能力 & 身辺処理能力 \\
\hline A & $6: 1$ & 우 & $\begin{array}{l}\text { 発育pや不良 } \\
\text { p户幅育型 }\end{array}$ & $\begin{array}{l}\text { ひとり踄き不能 } \\
\text { 手引き行可能 }\end{array}$ & 音声言語なし & ほとんど介助 \\
\hline B & $2: 5$ & $\hat{o}$ & $\begin{array}{l}\text { 発育やや不良 } \\
\text { やせ型 }\end{array}$ & $\begin{array}{l}\text { ひとり立ち不能 } \\
\text { 運動能力きわ不良 }\end{array}$ & 音声言語なし & 全面介助 \\
\hline $\mathrm{C}$ & $4: 5$ & 우 & $\begin{array}{l}\text { 発育甭良 } \\
\text { 幅型 }\end{array}$ & $\begin{array}{l}\text { ひとり歩き可能 } \\
\text { ひとり遊び多し }\end{array}$ & 音声言語なし & ほとんど介助 \\
\hline $\mathrm{D}$ & $2: 3$ & $\hat{o}$ & $\begin{array}{l}\text { 発育普通 } \\
\text { 普通型 }\end{array}$ & $\begin{array}{l}\text { ひとり歩き不能 } \\
\text { 手引き歩行可能 } \\
\text { 動に対する積極性なし }\end{array}$ & $\begin{array}{l}\text { 名詞を十数語話す } \\
\text { 言語理解はめる }\end{array}$ & ほとんど介助 \\
\hline $\mathrm{E}$ & $4: 3$ & $\hat{o}$ & $\begin{array}{l}\text { 発育良好 } \\
\text { 普通型 }\end{array}$ & $\begin{array}{l}\text { 指示には従えないが運動 } \\
\text { 能力は普通 }\end{array}$ & 音声言語なし & ほとんど介助 \\
\hline $\mathrm{F}$ & $3: 0$ & 우 & $\begin{array}{l}\text { 発育良好 } \\
\text { 頑健型 }\end{array}$ & $\begin{array}{l}\text { 方向性はないがひとり歩 } \\
\text { き可能 }\end{array}$ & $\begin{array}{l}\text { 音声言語なし } \\
\text { 言語理解はある }\end{array}$ & $\begin{array}{l}\text { 介助を求める } \\
\text { 自分でできるるの } \\
\text { すある }\end{array}$ \\
\hline G & $3: 2$ & $\hat{0}$ & $\begin{array}{l}\text { 登育良好 } \\
\text { 普通型 }\end{array}$ & 運動能力良し & 言語能力良好 & $\begin{array}{l}\text { 少しの介助で身辺 } \\
\text { 処理ができる }\end{array}$ \\
\hline $\mathrm{H}$ & $4: 10$ & $\hat{0}$ & $\begin{array}{l}\text { 登育普通 } \\
\text { 普通型 }\end{array}$ & $\begin{array}{l}\text { ひとり歩き可能 } \\
\text { 動作に忑い }\end{array}$ & $\begin{array}{l}\text { 「くり返し」「おうむ } \\
\text { 返し」がほとんど }\end{array}$ & $\begin{array}{l}\text { 少しの介助で身辺 } \\
\text { 处理ができる }\end{array}$ \\
\hline I & $3: 9$ & 우 & $\begin{array}{l}\text { 発育普通 } \\
\text { 虚弱型 }\end{array}$ & $\begin{array}{l}\text { ひとり歩き可能 } \\
\text { 運動に対する積極性なし }\end{array}$ & 会話は少し可能 & $\begin{array}{l}\text { 少しの介助で身辺 } \\
\text { 处理できる }\end{array}$ \\
\hline$J$ & $5: 2$ & $\hat{\delta}$ & $\begin{array}{l}\text { 発育良好 } \\
\text { 幅育型 }\end{array}$ & $\begin{array}{l}\text { ひとり歩き不能 } \\
\text { 運動能極めて不良 }\end{array}$ & 音声言語なし & 全面介助 \\
\hline K & $3: 3$ & $\hat{\delta}$ & $\begin{array}{l}\text { 嬁㕕良好 } \\
\text { 型 }\end{array}$ & $\begin{array}{l}\text { 方向性はないがひとり歩 } \\
\text { き可能 }\end{array}$ & 音声言語なし & ほとんど介助 \\
\hline
\end{tabular}

第6表 少 食巟 の特徵

\begin{tabular}{|c|c|c|c|c|c|c|}
\hline 氏名 & 年令 & 性 & 身体発育 & 運動能力 & 言語能力 & 身辺処理能力 \\
\hline $\mathrm{L}$ & $2: 0$ & $\hat{0}$ & $\begin{array}{l}\text { 発育不良 } \\
\text { やせ型 }\end{array}$ & $\begin{array}{l}\text { ひとり歩き不能 } \\
\text { 支兄歩き可能 }\end{array}$ & 片言を話す & ほとんど介助 \\
\hline M & $3: 9$ & 우 & $\begin{array}{l}\text { 発育不良 } \\
\text { やせ型 }\end{array}$ & $\begin{array}{l}\text { ひとり歩き不能 } \\
\text { 支え歩き可能 }\end{array}$ & 音声言語なし & 全面介助 \\
\hline $\mathrm{F}$ & $3: 0$ & 우 & $\begin{array}{l}\text { 發育良好 } \\
\text { 覑健型 }\end{array}$ & $\begin{array}{l}\text { 方向性はないがひとり歩 } \\
\text { き可能 }\end{array}$ & $\begin{array}{l}\text { 音声言語なし } \\
\text { 言語理解はある }\end{array}$ & $\begin{array}{l}\text { 介助を求める } \\
\text { 自分でさるもの } \\
\text { もある }\end{array}$ \\
\hline $\mathrm{N}$ & $4: 3$ & 우 & $\begin{array}{l}\text { 登育丕良 } \\
\text { 普通型 }\end{array}$ & $\begin{array}{l}\text { ひとり立ち不能 } \\
\text { 運動能力きわ不良 }\end{array}$ & $\begin{array}{l}\text { 片言を話す } \\
\text { 扣うも返し }\end{array}$ & 全面介助 \\
\hline $\mathrm{O}$ & $4: 9$ & $\hat{\delta}$ & $\begin{array}{l}\text { 発育不良 } \\
\text { やせ型 }\end{array}$ & $\begin{array}{l}\text { ひとり歩き可能 } \\
\text { 運動への積極性なし }\end{array}$ & 言語力は普通 & $\begin{array}{l}\text { 少しの介助で身辺 } \\
\text { 処理できる }\end{array}$ \\
\hline $\mathrm{D}$ & $2: 3$ & $\hat{\delta}$ & $\begin{array}{l}\text { 發育普通 } \\
\text { 普通型 }\end{array}$ & $\begin{array}{l}\text { ひとり歩き不能 } \\
\text { 手引き歩行可能運動に対 } \\
\text { する積極性なし }\end{array}$ & $\begin{array}{l}\text { 名詞を十数語話す } \\
\text { 言語理解はある }\end{array}$ & ほとんど介助 \\
\hline $\mathrm{P}$ & $6: 10$ & 우 & $\begin{array}{l}\text { 登育普通 } \\
\text { 虚弱型 }\end{array}$ & $\begin{array}{l}\text { ひとり歩き少し可能 } \\
\text { 運動統制力が悪い }\end{array}$ & $\begin{array}{l}\text { 「くり返し」言語 } \\
\text { 「扮うむ返し」がほ } \\
\text { とんど }\end{array}$ & ほとんど介助 \\
\hline B & $2: 5$ & $\hat{o}$ & $\begin{array}{l}\text { 発育やや不良 } \\
\text { やせ型 }\end{array}$ & $\begin{array}{l}\text { ひとり立ち不能 } \\
\text { 運動能力極めて不良 }\end{array}$ & 音声言語なし & 全面介助 \\
\hline I & $3: 9$ & 우 & $\begin{array}{l}\text { 発育普通 } \\
\text { 虚弱型 }\end{array}$ & $\begin{array}{l}\text { ひとり歩き可能 } \\
\text { 運動に対する積極性なし }\end{array}$ & 会話は少し可能 & $\begin{array}{l}\text { 少しの介助で身辺 } \\
\text { 処理できる }\end{array}$ \\
\hline $\mathrm{K}$ & $3: 3$ & $\hat{o}$ & $\begin{array}{l}\text { 発育良好 } \\
\text { や型 }\end{array}$ & $\begin{array}{l}\text { 方向性はないがひとり歩 } \\
\text { き可能 }\end{array}$ & 音声言語なし & ほとんど介助 \\
\hline
\end{tabular}


偏食児11名（偏食食品 6 以上の者，，少食児10名（カロリー，蛋白質共に「不足」の者）について，身体発 育 $^{10)}$, 運動能力 ${ }^{11)}$ ，言語能力 ${ }^{12)}$ ，身辺処理能力 ${ }^{13)}$ を調べ，とれを表示すると第 5 表および第 6 表のよ5になる。

この結果を整理すると, 次の諸点が指摘される。

(1)偏食児では身体発育の不良の者は少なく，形態的健康度においても問題のある者は少ない。

(2)少食児では身体発育の不良の者が半数を占め, 形態的健康度に和いても問題のある者が多い。

(3)偏食览, 少食児共に運動能力の面で極めて遅れている者が半数を占めている。

(4)偏食児，少食児共に言語能力に遅れのある者が多いが，その傾向は偏食児に特に強い。

(ら)偏食児，少食児共に身辺処理が自立していない者がほとんどである。 以上の諸点に拈いて重要な事は, 第 1 に偏食は身体発育に影響を及ぼしていないが，少食は悪影響を及ぼして いる事である。（結論 6 ）第 2 には，偏食児や少食児はその多くが発達遅滞児である事である。（結論 7）し かし，この結論は，偏食や少食が発達遅漁の原因となっているのではなく，むしろ反対に，発達遅滞が偏食や 少食の原因になっている事を示しているとみるべきであうう。

\section{$\mathrm{V}$ 結 論}

以上の考察によって，盲幼児の食生活の実態について 7 つの結論が得られた。これらを列挙すると次のと拉 りである。

結論 $1 \cdots \cdots$ 盲幼児には偏食の傾向が強くみられる。

結論 $2 \cdots \cdots$ 盲幼児の偏食の原因は視力欠損ではない。

結論 $3 \cdots$...偏食は盲幼児全体の傾向ではなく, 極度に偏食を示寸者が多いだけであり, 盲幼児の大半は何ら 偏食と関係はない。

結論 $4 \cdots \cdots$ 育幼児には少食の者が多くみられる。

結論 5 ……盲幼児は, 放任された環境の中で, 食習慣を形成し，偏食や少食に対しても積極的な指導を受け ていない者が多い。

結論 $6 \cdots \cdots$...偏食は身体発育に影響を及ぼしていないが，少食は悪影響を及ぼしている。

結論 7 ……偏食や少食の盲幼児には発達遅滞を示している者が非常に多い。

さらに,これら 7 つの結論を整理すると，本研究の結論として次の 2 点に集約される。

\section{結論 I}

盲幼児には，偏食や少食が多い。しかしこれは盲幼児なら誰でも偏食や少食になりやすい事を示しているわ けではない。偏食や少食を示しやすいのは盲幼児の中でも発達遅滞児である。また，偏食と少食を比較した場 合，少食が身体発育に影響するという点で問題は大きい。

\section{結論 II}

盲幼児は, 放任型の育児態度で接触されている者が多い。特に発達遅滞のある場合はその傾向は強くなる事 は当然である。この母親の育児態度が盲幼児の偏食や少食の原因を成している。

\section{$\mathrm{VI}$ 問 題 点}

本研究では偏食と少食の問題を中心に盲幼児の食生活の実態を解明した。本研究では調査対象も少なく，コ ントロールダループも普通児をとっていない点で, 研究法に問題はあるが, 盲幼児の偏食・少食の問題点を発 
見できたという事で，今後の盲幼児の指導に何らかの示唆を与える事はできた。

本研究から得られた問題点の うち, 指導上特に問題となるのは次の 2 点である。

(1)偏食や少食を示す盲幼児が, 多く発達遅滞児である事は, 偏食や少食の矯正が食事指導という狭い領域 の中では不可能でめる事を示している。すなわち発達指導の一環として, 運動能力を高め運動量を増させ る指導や身辺処理能力を高める指導等を平行してはじめて，偏食や少食の矯正指導も期待できるのである。

(2)食事のしつけに括いて, 放任型の親が多くみられた事は, 単に偏食や少食の問題にとどまらず, 盲幼児 の発達に何らかの影響を与えることは当然である。したがって, 親に対する指導も極めて重要である事が 再認識される。 $<$ 注 $>$

1）文部省「児童生徒の心身障害に関する調査」（昭和 42 年）によると視力 0.04 未満の視覚障害児の出現率は 0. 015\%であり，盲幼児の出現率となればさらにこれより低い。

2）本論文では偏食とは「ある食品に対しいろいろな手だてをつくしても, それを取る事を拒否する事」と定 義している。

3）本論文では少食の基準をカロリーと蛋白質に求め，その両方の摂取量が所要量よりかなり少ない場合を少 食としている。

4)5）調査用紙は神奈川県教育委員会発行「学校給食のしおり」を参考に作成した。

6)7）本論文では視力 0 から眼前手動弁までを「全盲」, 視力指数弁以上 0.3 未満を「淮盲・弱視」として区分 している。

8)9）分析に扣いては，女子栄養大学出版部発行「食品成分表(1970)」を使用した。

10）身体発育に関しては，荻野忠則著「体位検査法」（日本文化科学社）を参考にした。

11)12）13）発達に関しては，観察によって評価した。

（受付：昭和 45 年 11 月 1 日）

$\overline{\text { 抄 } \quad \text { 録 }}$

\section{幼雌牛腸管から ${ }^{51} \mathrm{Cr}_{2} \mathrm{O}_{3}$ は吸収されない}

Recovery of radioactive chromic oxide from the bouine gastrointestinal tract.

P. R. Utley, J. A. Boling, N. W. Bradley and R. E. Tucker: J. Nutr., 100, 1227 (1970)

消化試験て使用される全糞採集法は正確で信頼の 扣ける方法であるが，時間と労力と技術を要するの で，簡便法として標識法が利用されるようになって 来た。標識法における標識物質として酸化第二ク口 么 $\left(\mathrm{Cr}_{2} \mathrm{O}_{3}\right)$ が使用されるが，回収率が $100 \%$ でな いという理由で使用をちゅうちょする研究者と, 回 収率が一定であるので, 消化率を調べるのに適して いると主張する研究者がいる。著者らは放射性の ${ }^{51} \mathrm{Cr}_{2} \mathrm{O}_{3}$ を使って腸管からの吸収の有無, 回収率を 調べまた非放射性 $\mathrm{Cr}_{2} \mathrm{O}_{3}$ の回収率も同時に測定し
た。幼雌牛 6 頭を 30 日間 $0.2 \%$ の $\mathrm{Cr}_{2} \mathrm{O}_{3}$ を含む飼料 で予備飼育しその後16日間制限給䭒 ( $3 \mathrm{~kg} / \mathrm{day})$, 後 半 9 日間の排泄物を採集した。排泄物採集開始第 1 日目に6頭当り合計 $146 \mu \mathrm{C}$ の ${ }^{51} \mathrm{Cr}_{2} \mathrm{O}_{3}$ を経口投与し, 経時的に蓓, 尿, 血中の放射能を測定した。その結 果, 尿, 血中への放射能の取り込みは認められず, 粪中の放射能は投与12時間後から検出され 24 ～36時 間でピークに達した。放射能の回收率は投与後 216 時間で $87.2 \%$ であった。一方非放射性 $\mathrm{Cr}_{2} \mathrm{O}_{3}$ の回収 率は平均 $98 \%$ であった。放射性 ${ }^{51} \mathrm{Cr}_{2} \mathrm{O}_{3}$ と非放射 性 $\mathrm{Cr}_{2} \mathrm{O}_{3}$ の回収率の差について著者らは論じていな いが，これらの基礎の上に，全責採集法と標識法に よる消化試験成績を比較すると非常によく一致し統 計的な差を認めなかった。

(江指) 